\title{
Desiccation of herpetofauna on roadway exclusion fencing
}

\author{
Sean P. Boyle ${ }^{1, *}$, Rachel Dillon ${ }^{1}$, Jacqueline D. Litzgus ${ }^{1}$, and David Lesbarrères ${ }^{1}$ \\ ${ }^{1}$ Biology Department, Laurentian University, 935 Ramsey Lake Road, Sudbury, Ontario P3E 2C6 Canada \\ *Corresponding author: sboyle@laurentian.ca
}

Boyle, S.P., R. Dillon, J.D. Litzgus, and D. Lesbarrères. 2019. Desiccation of herpetofauna on roadway exclusion fencing. Canadian Field-Naturalist 133(1): 43-48. https://doi.org/10.22621/cfn.v133i1.2076

\begin{abstract}
Significant advances have been made to minimize the detrimental effects of roads on wildlife, but little is known about unintended negative consequences of mitigation strategies. Here, we present observations of adverse effects on herpetofauna of exclusion fencing at Presqu'ile Provincial Park, Ontario. A total of 15 individuals (one salamander, nine anurans, and five snakes) were found dead on unburied fencing, apparent victims of desiccation and/or heat exposure. Air temperatures did not differ between days when dead herpetofauna were and were not found on the fence; however, the fence surface was significantly warmer than the air. Our study shows that fence temperature and design may hinder animals escaping from the road to cooler refugia, and we discuss possible solutions.
\end{abstract}

Key words: Road ecology; road-effect mitigation; snakes; frogs; Presqu'ile Provincial Park; protected areas; southern Ontario

\section{Introduction}

Although herpetofauna are often overlooked compared with other taxa (Andrews et al. 2008, 2015; Popp and Boyle 2017), the negative effects of roads on these species are becoming increasingly clear and well documented (Gibbs and Shriver 2002; Andrews et al. 2008, 2015; Baxter-Gilbert et al. 2015). As a countermeasure, wildlife exclusion fencing (WEF), typically combined with crossing structures, is an increasingly common tool employed by biologists and conservation practitioners to mitigate the effects of road mortality on herpetofauna (Glista et al. 2009; Beebee 2013; van der Ree et al. 2015). In several instances, WEF has been shown to reduce the number of amphibians and reptiles killed in wildlife-vehicle collisions (Dodd et al. 2004; Aresco 2005; Colley et al. 2017; Markle et al. 2017). However, negative consequences associated with factors other than spatial ecology or road mortality have rarely been attributed to WEF (see Boarman et al. 1994; Ferronato et al. 2014; Eye et al. 2018). Because reducing road mortality is critical to maintaining population viability, WEF has important implications for conservation (Jaeger and Fahrig 2004). As such, documenting and understanding unintended negative consequences of WEF is an important step in conservation efforts.

Although road mortality is a major threat to herpetofauna, care must be taken to ensure that mitigation techniques used to address this threat do not produce undesirable side effects. Unfortunately, potential negative side effects of WEF on individuals and populations are somewhat difficult to predict and may include fence by-catch (Ferronato et al. 2014), an increase in the barrier effect (Jaeger and Fahrig 2004), disruption of important movement patterns (Clark et al. 2010; Rouse et al. 2011), hyperthermia from excessive sun exposure (Peaden et al. 2017; Eye et al. 2018), and increased road mortality rates resulting from improperly installed or maintained fencing (Baxter-Gilbert et al. 2015; Markle et al. 2017). Further complicating the matter is the variety of WEF materials, installation methods, terrain, and management regimes, with each combination presenting a unique set of potential side effects (e.g., solid versus mesh WEF; OMNRF 2016; Peaden et al. 2017).

In 2013, a six-year project was undertaken in Presqu'ile Provincial Park, Ontario, Canada $\left(43.9944^{\circ} \mathrm{N}\right.$, $77.7201^{\circ} \mathrm{W}$ ) to identify the local road-crossing patterns of herpetofauna (Boyle et al. 2017) and to test the effectiveness of various strategies to mitigate road mortality and habitat fragmentation. While completing road mortality surveys for this project, we noticed several desiccated herpetofauna on portions of a WEF during its installation. This prompted an investigation to determine whether the installation of the WEF, specifically the possibility that it could expose wildlife to extended periods of heat, was causing mortality of reptiles and amphibians. We hypothesized that if the WEF contributed to mortality associated

A contribution towards the cost of this publication has been provided by the Thomas Manning Memorial Fund of the Ottawa Field-Naturalists' Club. 
with desiccation, then the fence's bottom lip would be warmer than the air on days when we found dead animals. Second, if desiccation was a result of high temperatures, we expected that either the day or the day before we found desiccated animals on the fence would be warmer than days when no desiccated herpetofauna were found. To inform other road ecology practitioners and to contribute to the improvement of techniques, it is important to document negative secondary effects of various types of WEF and investigate potential solutions.

\section{Methods}

The main road of Presqu'ile has a posted speed limit of $40 \mathrm{~km} / \mathrm{h}$ and an average daily traffic volume of 3000 vehicles during July and August; thus, this is a high-impact roadway for wildlife (S.P.B. unpubl. data).

Installation of $\sim 1000 \mathrm{~m}$ of exclusion fencing (Animex vertical above-ground black exclusion fencing, Knowle, Hampshire, England) began in June 2016 and was completed in August 2016. Fencing was installed $\sim 1 \mathrm{~m}$ from the road's edge. The fencing was $0.865 \mathrm{~m}$ high and composed of solid, high-density polyethylene (HDPE) sheets, each $16.7 \mathrm{~m}$ long. At both the top and bottom of the fence, a lip $(0.15 \mathrm{~m})$ was folded over in opposite directions. The bottom lip, folded at a $90^{\circ}$ angle toward the road, increased stability of the fence once buried, and the upper lip, also folded at $90^{\circ}$ but facing away from the road, was intended to reduce the ability of animals to climb over the fence onto the road. The fencing was installed in two phases: in phase one, the entire fence was fastened against plastic support stakes for stability, with sheets zip-tied together through small holes drilled at either end (20 June to 15 August 2016); in phase two, the bottom lip was buried under $0.10 \mathrm{~m}$ of mixed aggregate (mid-August 2016). The addition of aggregate on the road side of the fence precluded the need to bury the fence in a trench, which is costly, labour intensive, and potentially ecologically destructive. On completion, the fence was contiguous except at three intersections (two roads and a bicycle path), where it was curved in on itself away from the road, to create a minimum $5 \mathrm{~m}$ turn-around.

We report here observations made during the midconstruction phase (i.e., from the time when the fence was installed until its bottom lip was covered with aggregate) when small vertebrates could move under the fence. Visual encounter surveys were conducted daily by foot beginning at $\sim 0915$ along the $1250 \mathrm{~m}$ fenced portion of the road from 1 May to 30 August 2016. During surveys, either S.P.B. or R.D. searched the road and roadside for live and dead herpetofauna. No effort was made to detect herpetofauna on the habitat (non-road) side of the fence.

Shaded air temperature at waist height was measured daily along the road at the start of each survey. In addition, we measured air and fence lip surface temperatures using a digital thermometer (Marathon, BA080008, $\pm 2.0^{\circ} \mathrm{C}$, San Leandro, California, USA) each time an animal (alive or dead) was found on the fence. Maximum air temperatures recorded at the nearest weather station, Trenton A, $\sim 20 \mathrm{~km}$ northeast of Presqu'ile were also referred to (Environment and Natural Resources 2016).

We completed all analyses in $\mathrm{R}$ v.3.4.1 ( $\mathrm{R}$ Development Core Team 2014). We used Wilcoxon signed rank tests to make three comparisons: (1) air temperature on days in July and August when we found dead herpetofauna versus days on which we found no dead herpetofauna on the fence's bottom lip, (2) maximum temperature of the previous day (Environment and Natural Resources 2016) on days when we found dead herpetofauna versus days when we found no herpetofauna on the fence's bottom lip, and (3) fence temperature versus air temperature when we observed dead herpetofauna.

\section{Results}

On 14 July 2016, a dead, desiccated, but undamaged Wood Frog (Lithobates sylvaticus) was discovered on the unburied bottom lip (road side) of the WEF. Typically, amphibians that are struck by vehicles sustain moderate to severe visible damage; thus, an apparently undamaged individual was noteworthy. Over the course of surveys, 12 amphibians (10 dead; one salamander and five species of frog; Table 1) and 10 snakes, all Common Gartersnakes (Thamnophis sirtalis; five dead; Table 1) were found on the bottom lip of the fencing. Additional individuals were observed before 14 July but no detailed notes were taken. Dead animals all appeared to be mostly intact, but had undergone various levels of desiccation (Table 1). Although not the main goal of our study, it is noteworthy that all of the desiccated herpetofauna were found at previously identified road mortality hotspots (Boyle et al. 2017). Of the 10 dead amphibians, all but two were fully desiccated (Figure 1a). The two live frogs detected on the fence behaved normally but appeared to be unable to find a way through the fence, despite the bottom lip being unburied. In addition, one of the live snakes was coiled on the bottom lip of the fence, possibly basking, while the others demonstrated signs of stress (i.e., erratic movements, sluggishness, mouth gaping) possibly because of dehydration.

We did not find differences in air temperature between days we did or did not find deceased herpetofauna $(W=155, P=0.30)$, nor between the 
TABLE 1. Reptiles and amphibians observed dead or alive on Animex exclusion fencing in Presqu'ile Provincial Park, Ontario, from 14 July to 30 August 2016, along with demographic and climatic information for each sighting.

\begin{tabular}{|c|c|c|c|c|c|c|c|}
\hline Date & Time & Weather & Species* & Sex/lifestage $\dagger$ & $\begin{array}{l}\text { Air } \\
\text { temperature, }{ }^{\circ} \mathrm{C}\end{array}$ & $\begin{array}{l}\text { Fence } \\
\text { temperature, }{ }^{\circ} \mathrm{C}\end{array}$ & $\begin{array}{l}\text { Dead or } \\
\text { alive }\end{array}$ \\
\hline 9 Aug. & 0935 & Sunny & Blue-spotted Salamander & Juvenile & 27.6 & 31.8 & Dead \\
\hline 12 Aug. & 0927 & Overcast & Gray Treefrog & Juvenile & 28.5 & 32.1 & Dead \\
\hline 12 Aug. & 0932 & Overcast & Gray Treefrog & Juvenile & 25.1 & 35.4 & Dead \\
\hline 12 Aug. & 0939 & Overcast & Gray Treefrog & Juvenile & 25.1 & 35.4 & Dead \\
\hline 5 Aug. & 0900 & Light rain & American Bullfrog & Female & 26.7 & 29.1 & Alive \\
\hline 12 Aug. & 1339 & Overcast & Green Frog & Adult & 25.1 & 35.4 & Dead \\
\hline 12 Aug. & 1039 & Overcast & Northern Leopard Frog & Adult & 25.1 & 35.4 & Dead \\
\hline 5 Aug. & 0927 & Overcast & Northern Leopard Frog & Juvenile & 27.3 & 29.2 & Dead \\
\hline 14 Jul. & 0940 & Overcast & Wood Frog & Juvenile & 24.3 & 27.1 & Alive \\
\hline 9 Aug. & 0935 & Sunny & Wood Frog & Juvenile & 27.6 & 31.8 & Dead \\
\hline 12 Aug. & 1139 & Overcast & Wood Frog & Juvenile & 25.1 & 35.4 & Dead \\
\hline 12 Aug. & 1239 & Overcast & Wood Frog & Juvenile & 25.1 & 35.4 & Dead \\
\hline 22 Jul. & 0925 & Sunny & Common Gartersnake & Adult & 24.0 & 27.2 & Alive \\
\hline 15 Aug. & 1002 & Mostly cloudy & Common Gartersnake & Adult & 23.6 & 27.2 & Dead \\
\hline 22 Aug. & 1120 & Overcast & Common Gartersnake & Adult & 21.1 & 29.3 & Alive \\
\hline 2 Aug. & 0926 & Sunny & Common Gartersnake & Female & 23.9 & 25.6 & Alive \\
\hline 23 Aug. & 1004 & Sunny & Common Gartersnake & Female & 24.4 & 26.9 & Alive \\
\hline $17 \mathrm{Jul}$. & 0924 & Sunny & Common Gartersnake & Juvenile & 21.6 & 22.6 & Alive \\
\hline 29 Jul. & 0941 & Partly cloudy & Common Gartersnake & Juvenile & 26.3 & 32.1 & Dead \\
\hline 2 Aug. & 0940 & Sunny & Common Gartersnake & Juvenile & 23.9 & 25.6 & Dead \\
\hline 2 Aug. & 1024 & Sunny & Common Gartersnake & Juvenile & 28.7 & 31.9 & Dead \\
\hline 5 Aug. & 0930 & Sunny & Common Gartersnake & Juvenile & 26.7 & 31.2 & Dead \\
\hline
\end{tabular}

Note: Although all individuals demonstrated some desiccation, this was not quantified in situ.

*Blue-spotted Salamander (Ambystoma laterale), Gray Treefrog (Hyla versicolor), American Bullfrog (Lithobates catesbeianus), Green Frog (Lithobates clamitans), Northern Leopard Frog (Lithobates pipiens), Wood Frog (Lithobates sylvaticus), and Common Gartersnake (Thamnophis sirtalis).

$\dagger$ Snakes designated as "adult" were either not captured or not sexed to minimize additional stress on the animal.

maximum temperatures of days previous to detections versus those without detections ( $\mathrm{W}=156, P=$ $0.91)$. However, the fence was significantly warmer than the air ( $\mathrm{W}=96, P=0.002$; Table 2$)$ on days when dead herpetofauna were observed on the fence.

\section{Discussion}

Contrary to our expectations, air temperature was a poor predictor of the presence of dead animals. However, the fence itself was warmer than the air when we found dead herpetofauna, supporting our hypothesis that the fence contributed to the desiccation and mortality. Individuals that moved to the edge of the fence in an attempt to exit the road's right of way would have bypassed the exit path available underneath the fence because of the folded lip. Thus, we conclude that the fence contributed to the observed mortality, likely by reducing the ability of animals to return to cooler refugia.

\section{Consequences of fencing and thermal exposure}

Although negative interactions between herpetofauna and exclusion fencing have been previously acknowledged (Boarman et al. 1994; Clark et al. 2010; Rouse et al. 2011; Ferronato et al. 2014; Baxter-
Gilbert et al. 2015; OMNRF 2016), we are unaware of any reports of herpetofauna being found dead or desiccated on the fencing surface. Peaden et al. (2017) suggested mesh exclusion fencing may subject herpetofauna to an increased level of sun exposure because of time they spend trying to bypass it. Similarly, Eye et al. (2018) suggested increased time spent navigating WEF could be detrimental because of increased heat exposure. We witnessed animals that had breached the fence line, but were unable to return to the habitat side and spent much time walking the length of the fencing trying to find a breach. However, we suspect that solid fencing may partly alleviate the threat of sun exposure (especially in heavily vegetated conditions or on the habitat side). It seems likely that the mortality documented here is the result of extended heat stress leading to hyperthermia and desiccation.

Roads constitute an ecological trap for reptiles because they are attractive for thermoregulation (Andrews et al. 2015) and are used as nesting sites by some freshwater turtle species (Steen and Gibbs 2004). Furthermore, if animals that are initially attracted to the road's heat for thermoregulation or nesting opportunities cannot avoid extreme 

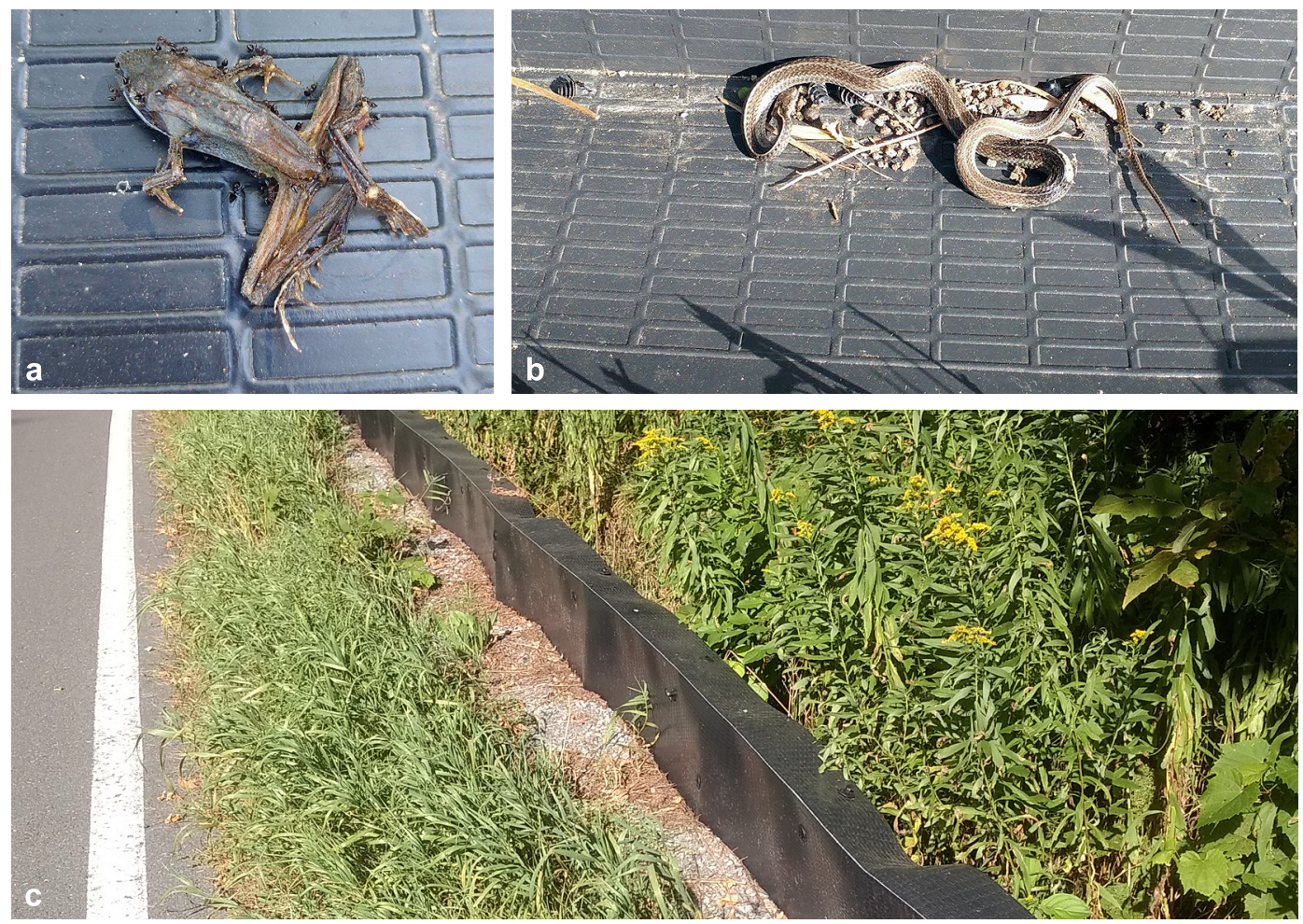

Figure 1. Examples of herpetofauna found dead along the bottom lip (facing the road) of Animex fencing in Presqu'ile Provincial Park, Ontario. a. Heavily desiccated adult Wood Frog (Lithobates sylvaticus) with ants scavenging the carcass. b. Partly desiccated adult female Common Gartersnake (Thamnophis sirtalis). Note: The unburied bottom lip of the fence is visible in photo b. c. Exclusion fencing buried by approximately $0.1 \mathrm{~m}$ of mixed aggregate. The completion of the fence may have contributed to fewer frogs on the road. Photos: Rachel Dillon (a,b), 2016; Sean Boyle (c), 2017.

temperatures by returning to cooler refugia, they risk desiccation and possibly death (Heatwole and Taylor 1987). Although air and fence temperatures were below the thermal maxima of $T$. sirtalis (voluntary $=35^{\circ} \mathrm{C}$, critical $=38-41^{\circ} \mathrm{C}$; Brattstrom 1965), on some days, these maxima were approached, and the thermal tolerance of snakes decreases if they are dehydrated (i.e., because of prolonged exposure; Ladyman and Bradshaw 2003). Particularly at risk may be amphibians and juvenile snakes because of their higher surface area to volume ratio. Although we cannot estimate how long the individuals we detected were exposed to extreme heat, even a short time could cause heat stress, especially if the individuals were already compromised or dehydrated quickly once on the fence's bottom lip.

\section{Potential sources of bias}

We considered alternative causes of mortality. Because we did not observe obvious wounds on the carcasses, mortality from failed depredation is unlikely. Although it is possible that individuals were struck by traffic and subsequently ricocheted onto the fence, this also seems unlikely for multiple reasons. First, individuals were largely undamaged and roughly maintained their shape (Figure 1a,b);

TABLE 2. Average shaded air and fence temperatures recorded on detecting live and dead herpetofauna along Animex exclusion fencing in Presqu'ile Provincial Park, Ontario, in July and August 2016.

\begin{tabular}{lcc}
\hline \hline Herpetofauna & Air temperature, ${ }^{\circ} \mathrm{C} \pm \mathrm{SE}$ & Fence temperature, ${ }^{\circ} \mathrm{C} \pm \mathrm{SE}$ \\
\hline Living animals & & $28.1 \pm 1.0$ \\
$\quad$ Amphibians $(n=2)$ & $25.5 \pm 1.2$ & $26.3 \pm 1.1$ \\
$\quad$ Snakes $(n=5)$ & $23.0 \pm 0.7$ & $33.73 \pm 0.7$ \\
Dead animals & & $29.6 \pm 1.3$ \\
$\quad$ Amphibians $(n=10)$ & $26.16 \pm 0.4$ & $25.8 \pm 0.9$ \\
$\quad$ Snakes $(n=5)$ & & \\
\hline \hline
\end{tabular}


typically, when snakes and amphibians are struck by cars, they suffer major injuries and are often flattened (S.P.B. pers. obs.). Second, we did not find individuals in the same desiccated condition on the grass or gravel between the fence and the road surface. Third, we saw live frogs and snakes on the bottom lip of the fencing (where we also found the dead individuals), indicating that they used, or at least travelled along the fence, possibly looking for a way to bypass it.

Although our detection rates for dead individuals were likely not $100 \%$ (because of scavengers, deterioration, and camouflage), we assumed that the detection probability was equal among all surveys and that detection rate was high because of the slow and methodical nature required for walking surveys specifically targetting small-bodied and often heavily damaged carcasses (Baxter-Gilbert et al. 2017). Given that the number of animals we found on surveys (Boyle et al. 2017) generally was much higher than the number we found on the fence (reported here), it is also likely that many individuals visited the fence but were able to escape before our surveys and, as such, the risk of thermal exposure and desiccation affects a relatively small proportion of the population.

\section{Precautions and solutions}

Although the number of dead animals observed on the mitigation fencing may be inconsequential compared with the road mortality that the fence prevents (i.e., thousands versus dozens; S.P.B. unpubl. data), this likely heat-related source of mortality should be addressed. Exclusion fencing is often installed in areas with at-risk species, where losing even a single individual could have significant consequences for population persistence (Steen and Gibbs 2004). A white version of this fencing, which has a lower heat capacity (Animex International 2016), could be used to limit hyperthermia risk for animals. In many mitigation scenarios, however, white fencing would not be appropriate because of its conspicuousness and increased rate of photo-degradation and consequent reduced lifespan (D. Swensson pers. comm. 8 March 2017).

Although fence temperature may have played a role in the observed mortality, it may be less important than the inability of animals to seek cooler locations. In the summer following our study, several animals were detected along the now back-filled fence line, but none were found dead. Three main differences were apparent between 2016 and 2017: (1) the road side of the fencing had now been backfilled with gravel, reducing access to the road; (2) the weather was much drier in 2016 than in 2017; and (3) vegetation was cut during fence installation in 2016, whereas, in 2017, it had recovered thus providing shade (Figure 1c).
Therefore, to reduce the risk of desiccation of herpetofauna, we recommend that backfilling the fence with gravel be viewed as a time sensitive priority and, when logistically possible, backfilling take place as the fence is installed. In addition, removal of vegetation should not occur during dry periods with high temperatures. Ramps (i.e., one-way jump-outs) built at frequent intervals in the fence to allow animals to exit the road and avoid prolonged heat exposure may also mitigate this issue; however, further investigation is required. Although mortality caused by overheating on fences is not likely to be a major source of population decline, especially when compared to the threat the fence mitigates (i.e., road mortality), it is an example of a conservation action that reduces one threat while potentially creating another and, thus, an additional issue to be considered when planning and installing road mortality mitigation devices.

\section{Author Contributions}

Writing - Original Draft: S.P.B., R.D., J.D.L., and D.L.; Writing - Review \& Editing: S.P.B., R.D., J.D.L., and D.L.; Conceptualization: S.P.B. and R.D.; Investigation: S.P.B. and R.D.; Formal Analysis: S.P.B. and R.D.

\section{Acknowledgements}

Funding for this project was provided by Laurentian University, Presqu'ile Provincial Park, Ontario Ministry of Natural Resources and Forestry (OMNRF) Species at Risk Stewardship Fund, Ontario Parks, and Friends of Presqu'ile Provincial Park. Opinions expressed in this paper are those of the authors and may not necessarily reflect the views and policies of the OMNRF. We thank Dean Swensson of Animex fencing for his expert opinion on white fencing. All observations and handling of live animals were done ethically, under approval by the Laurentian University Animal Care Committee. Research was conducted under animal care and use permits acquired by J.D.L. and D.L. The authors declare no conflicts of interest.

\section{Literature Cited}

Andrews, K.M., J.W. Gibbons, and D.M. Jochimsen. 2008. Ecological effects of roads on amphibians and reptiles: a literature review. Pages 121-143 in Urban Herpetology. Edited by J.C. Mitchell, R.E. Jung Brown, and B. Bartholomew. Society for the Study of Amphibians and Reptiles, Salt Lake City, Utah, USA.

Andrews, K., T.A. Langen, and R.P.J.H. Struijk. 2015. Reptiles: overlooked but often at risk from roads. Pages 271-280 in Handbook of Road Ecology. Edited by R. van der Ree, D.J. Smith, and C. Grilo. John Wiley and Sons, Chichester, United Kingdom.

Animex International. 2016. Fencing specifications and installation guides. Version 2.0. Knowle, Hampshire, 
England. Accessed 25 July 2019. https://animexfencing. com/assets/images/Animex-Wildlife-FencingSpecifications-Version-2.pdf.

Aresco, M.J. 2005. Mitigation measures to reduce highway mortality of turtles and other herpetofauna at a North Florida lake. Journal of Wildlife Management 69: 549 560. https://doi.org/10.2193/0022-541x(2005)069[0549: mmtrhm]2.0.co;2

Baxter-Gilbert, J.H., J.L. Riley, S.P. Boyle, D. Lesbarrères, and J.D. Litzgus. 2017. Turning the threat into a solution: using roadways to survey cryptic species and identify locations for conservation. Australian Journal of Zoology 66: 50-56. https://doi.org/10.1071/zo17047

Baxter-Gilbert, J.H., J.L. Riley, D. Lesbarrères, and J.D. Litzgus. 2015. Mitigating reptile road mortality: fence failures compromise ecopassages effectiveness. PLoS One 10: e0120537. https://doi.org/10.1371/journal. pone. 0120537

Beebee, T. 2013. Effects of road mortality and mitigation measures on amphibian populations. Conservation Biology 27: 657-668. https://doi.org/10.1111/cobi.12063

Boarman, W.I., M. Sazaki, K.H. Berry, G.O. Goodlett, W.B. Jennings, and A.P. Woodman. 1994. Measuring the effectiveness of a tortoise-proof fence and culverts: status report from first field season. Pages 126142 in Proceedings of the 1992 Desert Tortoise Council Symposium. Desert Tortoise Council, Palm Desert, California, USA.

Boyle, S.P., J.D. Litzgus, and D. Lesbarrères. 2017. Comparison of road surveys and circuit theory to predict hotspot locations for implementing road-effect mitigation. Biodiversity and Conservation 26: 3445-3463. https://oi.org/10.1007/s10531-017-1414-9

Brattstrom, B.H. 1965. Body temperature of reptiles. American Midland Naturalist 73: 376-422.

Clark, R.W., W.S. Brown, R. Stechert, and K.R. Zamudio. 2010. Roads, interrupted dispersal, and genetic diversity in timber rattlesnakes. Conservation Biology 24: 1059-1069. https://doi.org/10.1111/j.1523-1739.2009. 01439.x

Colley, M., S.C. Lougheed, K. Otterbein, and J.D. Litzgus. 2017. Mitigation reduces road mortality of a threatened rattlesnake. Wildlife Research 44: 48-59. https:// doi.org/10.1071/WR16130

Dodd, Jr., C. K., W.J. Barichivich, and L.L. Smith. 2004. Effectiveness of a barrier wall and culverts in reducing wildlife mortality on a heavily traveled highway in Florida. Biological Conservation 118: 619-631. https://doi. org/10.1016/j.biocon.2003.10.011

Environment and Natural Resources. 2016. Historical data: Trenton A Ontario. Government of Canada, Ottawa, Ontario, Canada. Accessed January 2019. July: https:// tinyurl.com/ yx9prbho; August: https://tinyurl.com/yxfv 6asn.

Eye, D.M, J.R. Maida, O.M. McKibban, K.W. Larson, and C.A. Bishop. 2018. Snake mortality and cover board effectiveness along exclusion fencing in British Columbia, Canada. Canadian Field-Naturalist 132: 3035. https://doi.org/10.22621/cfn.v132i1.2031

Ferronato, B.O., J.H. Roe, and A. Georges. 2014. Reptile bycatch in a pest-exclusion fence established for wildlife reintroductions. Journal for Nature Conservation
22: 577-585. https://doi.org/10.1016/j.jnc.2014.08.014

Gibbs, J.P., and W.G. Shriver. 2002. Estimating the effects of road mortality on turtle populations. Conservation Biology 16: 1647-1652. https://doi.org/10.1046/j.1523-17 39.2002. 01215.x

Glista, D.J., T.L. DeVault, and J.A. DeWoody. 2009. A review of mitigation measures for reducing wildlife mortality on roadways. Landscape and Urban Planning 91: 1-7. https://doi.org/10.1016/j.landurbplan.2008.11.001

Heatwole, H., and J.A. Taylor. 1987. Ecology of Reptiles. Second Edition. Surrey Beatty \& Sons, Chipping Norton, New South Wales, Australia.

Jaeger, J.A.G., and L. Fahrig. 2004. Effects of road fencing on population persistence. Conservation Biology 18: 1651-1657. https://doi.org/10.1111/j.1523-1739.2004. 00304.x

Ladyman, M., and D. Bradshaw. 2003. The influence of dehydration on the thermal preferences of the Western tiger snake, Notechis scutatus. Journal of Comparative Physiology B 173: 239-246. https://doi.org/10.1007/s00 360-003-0328-X

Markle, C.E., S.D. Gillingwater, R. Levick, and P. ChowFraser. 2017. The true cost of partial fencing. Wildlife Society Bulletin 41: 342-350. https://doi.org/ 10.1002/ wsb.767

OMNRF (Ontario Ministry of Natural Resources and Forestry). 2016. Best management practices for mitigating the effects of roads on amphibians and reptile species at risk in Ontario. OMNRF, Toronto, Ontario, Canada.

Peaden, J.M., A.J. Nowakowski, T.D. Tuberville, K.A. Buhlmann, and B.D. Todd. 2017. Effects of roads and roadside fencing on movements, space use, and carapace temperatures of a threatened tortoise. Biological Conservation 214: 13-22. https://doi.org/10.1016/j.biocon. 2017.07.022

Popp, J.N., and S.P. Boyle. 2017. Railroad ecology: underrepresented in science? Basic and Applied Ecology 19: 84-93. https://doi.org/10.1016/j.baae.2016.11.006

R Development Core Team. 2014. R: a language and environment for statistical computing. R Foundation for Statistical Computing, Vienna, Austria.

Rouse, J.D., R.J. Willson, R. Black, and R.J. Brooks. 2011. Movement and spatial dispersion of Sistrurus catenatus and Heterodon platirhinos: implications for interactions with roads. Copeia 2011: 443-456. https:// doi.org/10.1643/CE-09-036

Steen, D.A., and J.P. Gibbs. 2004. Effects of roads on the structure of freshwater turtle populations. Conservation Biology 18: 1143-1148. https://doi.org/10.1111/ j.1523-1739.2004.00240.x

van der Ree, R., J.W. Gagnon, and D.J. Smith. 2015. Fencing: a valuable tool for reducing wildlife-vehicle collisions and funnelling fauna to crossing structures. Pages 159-171 in Handbook of Road Ecology. Edited by R. van der Ree, D.J. Smith, and C. Grilo. John Wiley and Sons, Chichester, United Kingdom.

Received 6 April 2018

Accepted 8 February 2019 